\title{
LOW EFFICACY OF AN ULTRA-SHORT TERM, ONCE- DAILY DOSE TRIPLE THERAPY WITH OMEPRAZOLE, AZITHROMYCIN, AND SECNIDAZOLE FOR HELICOBACTER PYLORI ERADICATION IN PEPTIC ULCER
}

Fernando Marcuz Silva, Jaime Natan Eisig, Ethel Zimberg Chehter, Júlio Jovino da Silva and Antonio Atílio Laudanna

RHCFAP/3062

SILVA FM et al. - Low efficacy of an ultra-short term, once-daily dose triple therapy with Omeprazole, Azithromycin, and Secnidazole for Helicobacter pylori eradication in peptic ulcer. Rev. Hosp. Clín. Fac. Med. S. Paulo 57(1):9-14, 2002.

PURPOSE: To determine the eradication rate of an ultra-short treatment schedule for Helicobacter pylori infection in a population with peptic ulcers, using omeprazole, secnidazole, and azithromycin in a once-daily dose for 3 days.

METHODS: Thirty patients with peptic ulcer diagnosed by upper endoscopy and for Helicobacter pylori infection by rapid urease test and histologic examination received omeprazole $40 \mathrm{mg}$, secnidazole $1000 \mathrm{mg}$, and azithromycin $500 \mathrm{mg}$, administered once daily for 3 days. A follow-up exam was performed 12 weeks after the end of the treatment. Patients who were negative for Helicobacter pylori infection by rapid urease test and histologic examination were considered cured.

RESULTS: Patients were predominantly female, and the mean age was 50 years. Duodenal peptic ulcer was found in $73 \%$ of the patients. Eradication was achieved in 9 of the 28 (32\%) patients as determined from the follow-up endoscopic exam. The eradication rate by intention to treat was $30 \%$. Side effects were present in $3 \%$ of the patients, and compliance to treatment was total.

CONCLUSIONS: In spite of the low rate of side effects and good compliance, the eradication index was low. A possible drawback of this therapy is that it reduces the efficacy of macrolide and nitroimidazole compounds in subsequent treatments.

DESCRIPTORS: Peptic Ulcer/Treatment. Helicobacter pylori/Eradication. Secnidazole/Therapeutic use. Azithromycin/ Therapeutic use. Omeprazole/Therapeutic use.

When the presence of Helicobacter pylori is associated with peptic ulcer disease, eradication of this bacterium leads to the cure of the disease ${ }^{1}$, despite the fact that an optimal antibiotic schedule for its eradication has not yet been found ${ }^{2}$. The complexity and adverse effects of treatment and bacterial resistance to the medications provide different eradication rates, with several treatment regimens used to date ${ }^{3-5}$. As a general rule concerning bacteria that are sensitive to antibiotics, a longer period of treatment and different types of medication promote a higher eradica- tion rate for the chosen regimen ${ }^{6}$. However, this longer treatment regimen may also bring more side effects and result in lower compliance ${ }^{7}$.

Currently, therapy with 2 antibiotics plus a proton pump inhibitor, one of them clarithromycin and the other a nitroimidazole compound, have resulted in high eradication rates in several countries $^{8-12}$. Concerning our patients, the

From the Department of Clinical Gastroenterology, Hospital das Clínicas, Faculty of Medicine, University of São Paulo. treatment with the proton pump inhibitor, clarithromycin, and tinidazole eradicated $H$. pylori infection in $75 \%$ of those patients previously untreated ${ }^{13}$. Many studies report good eradication rates using a short-term treatment ${ }^{14-18}$. The possibility of using a regimen including macrolide and nitroimidazole compounds, which have prolonged plasma half-lives ${ }^{19-21}$, seemed to promise a short-term treatment with a high efficacy. Therefore, the main objective of this study was to assess the eradication rate of $H$. pylori achieved through the combined use of omeprazole, 
azithromycin, and secnidazole with a once-daily dose for 3 consecutive days in a cohort with peptic ulcer.

\section{PATIENTS AND METHODS}

Thirty consecutive outpatients who underwent upper digestive endoscopy were invited to participate in the study.

To be included in the study, patients had to have scar or active peptic ulcer in the stomach or duodenum and also had to be infected by $H$. pylori.

Patients were excluded from the study if they: 1) were previously treated for $H$. pylori infection, 2) had a previous antibiotic treatment (within the last 3 months), 3) were younger than 16 years of age, 4) were pregnant or lactating mothers, or 5) had previous gastric surgery or severe illness.

The Ethics and Science Committee of our institution approved the study, and all patients signed the written informed consent statement.

\section{The diagnose of the infection:}

H. pylori infection was diagnosed with the rapid urease test (RUT) and from histologic examination $(\mathrm{H} \& \mathrm{E}$ stain) of 2 gastric biopsy specimens (antrum and body). The criteria for determination of $H$. pylori eradication were a negative RUT and negative histology as determined from biopsy specimens obtained during upper digestive endoscopy performed 12 weeks after the end of treatment.

\section{The treatment:}

The schedule of treatment consisted of azithromycin $500 \mathrm{mg}$, secnidazole $1000 \mathrm{mg}$, and omeprazole $40 \mathrm{mg}$, given once daily for 3 consecutive days. At the end of treatment, the remaining pills were counted, side effects were checked, and patients were requested to discontinue the anti-ulcer medication, except for the symptomatic use of antacids.

Statistical analysis was performed using a SPSS v.8.0 (SPSS Inc., USA) software package.

\section{RESULTS}

The baseline characteristics of the population studied are shown on table 1. The predominant sex was female $(63 \%)$, and the percentage of duodenal ulcer was nearly 7 times higher than gastric ulcers. The mean age, close to the median age, was 50 years. Tobacco and non-steroidal anti-inflammatory drug (NSAID) users, as well as alcoholic patients, comprised a small number of the patients. Migrants were more numerous than the natives of the city of São Paulo.

Treatment compliance was fully successful (all patients took all doses of the medication adequately), and only 1 patient complained of a side ef-

Table 1 - Clinical data.

\begin{tabular}{lll}
\hline Patients (n) & & 30 \\
Age (years) & Mean & 51 \\
& Median & 50 \\
& Range & $27-77$ \\
Women & & $63 \%(19 / 30)$ \\
Migrants & $60 \%(18 / 30)$ \\
Blacks & $10 \%(3 / 30)$ \\
Duodenal ulcer & & $87 \%(26 / 30)$ \\
Tobacco users & & $20 \%(6 / 30)$ \\
NSAIDs users & & $17 \%(5 / 30)$ \\
Alcohol users & & $10 \%(3 / 30)$ \\
\hline
\end{tabular}

Table 2 - Helicobacter pylori eradication rates.

\begin{tabular}{lcc}
\hline & $\mathrm{n} / \boldsymbol{\%}$ & Confidence Interval (95\%) \\
\hline Per protocol $(\mathrm{n}=28)$ & $9 / \mathbf{3 2 \%}$ & $13 \%-50 \%$ \\
Intention to treat $(\mathrm{n}=30)$ & $9 / \mathbf{3 0} \%$ & $12 \%-47 \%$ \\
\hline
\end{tabular}

fect (a light skin rash). Two patients declined the follow-up endoscopic exam. They were excluded from the per protocol determination of the $H$. pylori eradication rate. The $H$. pylori eradication rate was $30 \%$ for all patients included in the study (intentionto-treat rate) and $32 \%$ for the patients who underwent endoscopic examination (per-protocol rate) (Table 2).

\section{DISCUSSION}

H. pylori eradication rates were very low in our series, even considering that ours is a developing country and that most patients were female (who tend to harbor strains resistant to secnidazole $)^{22}$. A higher $H$.pylori eradication rate was expected. It is well known that the prevalence of resistant bacteria varies from place to place in the same country ${ }^{22,23}$, but in our center, the prevalence of resistant bacteria was not known. The rates of eradication obtained were lower than the ones obtained in a previous study carried out with our patients with the use of clarithromycin, tinidazole, and a proton pump inhibitor given twice a day for 7 days ${ }^{13}$, where a $75 \%$ eradication rate was achieved for those patients who were previously untreated. Several studies performed in Brazilian centers with a triple-agent treatment regimen of a week or less have also proved effective ${ }^{24-27}$.

Azithromycin is said to be a compound similar to clarithromycin for the eradication of $H$. pylori ${ }^{28,29}$. Unfortunately this antibiotic is not always applicable, since it has a lower reliability than clarithromycin for a 3-day 
treatment, alone or in combination with other drugs ${ }^{30-33}$. Secnidazole is a nitroimidazole derivative and does not differ from metronidazole. However, it has a prolonged plasma half-life, and for this reason, secnidazole is the firstchoice treatment for many diseases ${ }^{19}$.

For those patients from a disadvantaged cultural and social background, as in our series, shorter and simpler schedules result in better eradication rates. Shorter, simpler treatment regimens lead to higher compliance, lower cost, and fewer side effects, which are important issues for good outcomes ${ }^{34,35}$. From this standpoint, the therapy used in this study was close to the optimal treatment. All patients took their medication properly, and only one reported side effects.

The use of 2 antibiotics with an even longer plasma half-life in a daily dose, plus the ultra short-term use of omeprazole (only 3 days), can jeopardize the efficacy of the regimen.

In fact, the number of intakes and in loco action of the antibiotics might play an important role on $H$. pylori eradication, since it is possible that the ultra-short regimen reduces antibiotic concentration on the gastric mucosa ${ }^{36}$. Omeprazole induces bacterial growth, and short-term use can prevent an opportunity for a more powerful antibacterial action ${ }^{37}$.
Increasing the number of days of the regimen would make the treatment similar to the regimen that uses the proton pump inhibitor, tinidazole, and clarithromycin twice a day for 7 days, which would result in abandoning the main attractive features of the regimen reported here, that is, its simplicity, shorter schedule, lower cost, and reduced side effects.

Nevertheless, the use of this treatment regimen might reduce the efficacy of macrolides and nitroimidazoles in later treatments for those patients in whom we were unable to eradicate $H$. pylori infection ${ }^{38,39}$.
SILVA FM e col. - Baixa eficácia de um tratamento tríplice de curta duração, em dose única diária, para erradicação do Helicobacter pylori em pacientes ulcerosos com Omeprazol, Azitromicina e Secnidazol.

Rev. Hosp. Clín. Fac. Med. S. Paulo 57(1):9-14, 2002.
OBJETIVO: Testar a eficácia de um esquema ultra-curto de erradicação do H. pylori em uma população de ulcerosos, usando Omeprazol, Secnidazol e Azitromicina em dose única diária por três dias.

PACIENTES E MÉTODOS: Trinta doentes portadores de úlcera péptica, documentada por exame endoscópico e com infecção pelo $H$. pylori confirmada pelo teste da urease e exame histológico, foram tratados com Omeprazol 40mg, Secnidazol $1000 \mathrm{mg}$ e Azitromicina 500mg dados em dose única diária por três dias. Em controle endoscópico realizado 12 se- 
manas após o término do tratamento, foram considerados curados da infecção os pacientes que apresentaram o teste da urease e exame histológico negativos para a bactéria.

RESULTADOS: As mulheres predominaram $(63 \%)$, a idade média foi de $50 \operatorname{anos}$ e a úlcera duodenal foi identificada em $73 \%$ dos pacientes. Nos 28 doentes que realizaram o exa- me de controle, a erradicação foi constatada em nove (32\%). Por intenção de tratamento o índice foi de $30 \%$. A adesão ao tratamento foi total e houve um baixo índice de efeitos adversos (3\%).

CONCLUSÃO: O esquema apesar de proporcionar alta adesão e poucos efeitos adversos, apresenta baixa taxa de erradicação, mesmo em se considerando um país em desenvolvimento e apre- senta como possível agravante comprometer a eficácia de outros macrolídeos e nitroimidazólicos no uso de esquemas de erradicação subseqüentes.

DESCRITORES: Úlcera péptica/ terapia. Helicobacter pylori/terapia. Secnidazol/uso terapêutico. Azitromicina/uso terapêutico. Omeprazol/ uso terapêutico.

\section{REFERENCES}

1. PENSTON JG - Review article: clinic aspects of Helicobacter pylori eradication therapy in peptic ulcer disease. Aliment Pharmacol Ther 1996; 10 (suppl 4): 469-486.

2. UNGE P \& BERSTAD A - Pooled analysis of anti-Helicobacter pylori treatment regimens. Scand J Gastroentrol 1996; 31(suppl 220): 27-40.
3. GLUPCZYNSKI I \& BURETTE A - Drug therapy for Helicobacter pylori infection: Problems and pitfalls. Am J Gastroenterol 1990; 85: $1545-1551$.

4. CUTLER AF \& SCHUBERT TT - Patient factors affecting Helicobacter pylori eradication with triple therapy. Am J Gastroenterol 1993; 88: 505-509. 
5. PIPKIN GA, WILLIAMSON R \& WOOD JR - Review article: oneweek clarithromycin triple therapy regimens for eradication of Helicobacter pylori. Aliment Pharmacol Ther 1998; 12: 823-837.

6. HUANG J \& HUNT RH - The importance of clarithromycin dose in the management of Helicobacter pylori infection: a meta-analysis of triple therapies with a proton pump inhibitor, clarithromycin and amoxicillin or metronidazole. Aliment Pharmacol Ther 1999; 13:719-729.

7. SAVARINO V, ZENTILIN P, BISSO G et al. - Optimal duration of therapy combining ranitidine bismuth citrate with clarithromycin and metronidazole in the eradication of Helicobacter pylori infection. Aliment Pharmacol Ther 1999; 13: 43-47.

8. CHIBA N, RAO BV, RADEMAKER JW et al. - Meta-analysis of the efficacy of antibiotic therapy in eradicating Helicobacter pylori. Am J Gastorenterol 1992; 87: 1716-1727.

9. NATIONAL Institutes of Health Consensus Development Conference Statement: Helicobacter pylori in peptic ulcer disease. J A M A 1994; 272: 65-69.

10. CURRENT European concepts in the management of Helicobacter pylori infection. The Maastricht Consensus Report. European Helicobacter pylori Study Group. Gut 1997; 41: 8-13.

11. LAM SK \& TALLEY NJ - Report of the 1997 ASIA Pacific Consensus Conference on the management of Helicobacter pylori infection. J Gastroenterol Hepatol 1998; 13: 1-12.

12. HUNT RH, FALLONE CA \& THOMSON AB - Canadian Helicobacter pylori Consensus Conference update: infections in adults. Canadian Helicobacter Study Group. Can J Gastroenterol 1999; 13: 213217.

13.ZATERKA S, SILVA FM, EISIG JN et al. - Helicobacter pylori eradication after 7 days triple therapy with PPI bid + tinidazole $500 \mathrm{mg}$ bid+ clarithromycin 250mg bid: Risk factors related to treatment failure. Am J Gastroenterol 1997; 92: 1629.

14. TUCCI A, POLI L, PAPARO GF et al. - Weekend therapy for the treatment of Helicobacter pylori infection. Am J Gastroenterol 1998; 93: 737-742.

15. SAVARINO V, ZENTILIN P, BISSO G et al. - Optimal duration of therapy combining ranitidine bismuth citrate with clarithromycin and metronidazole in the eradication of Helicobacter pylori infection. Aliment Pharmacol Ther 1999; 13: 43-47.

16. CAMMAROTA G, CANNIZZARO O, OJETTI V et al. - Five-day regimens containing Ranitidine Bismuth Citrate plus high-dose clarithromycin and either amoxycillin or tinidazole for Helicobacter pylori infection. Aliment Pharmacol Ther 2000; 14:73-77.

17. TREVISANI L, SARTORI S, CASELLI M et al. - A four-day low dose triple therapy regimen for the treatment of Helicobacter pylori infection. Am J Gastroenterol 1998; 93: 390-393.

18. CALVET X, TITO L, COMET R et al. - Four-day, quadruple therapy with amoxicillin, clarithromycin, tinidazole and omeprazole to cure Helicobacter pylori infection: a pilot study. Helicobacter 2000; 5: $52-56$

19. GILLIS JC \& WISEMAN LR - Secnidazole. A review of its antimicrobial activity, pharmacokinetic properties and therapeutic use in the management of protozoal infections and bacterial vaginosis. Drugs 1996; 51: 621-638.
20. LODE H, BORNER K, KOEPPE P et al. - Azithromycin - review of key chemical, pharmacokinetic and microbiological features. J Antimicrob Chemoter 1996; 37(Suppl C): 1-8.

21. DUNN CJ \& BARRADELL LB - Azithromycin. A review of its pharmacological properties and use as 3-day therapy in respiratory tract infections. Drugs 1996; 51: 483-505.

22. QUEIROZ DMM, COIMBRA RS, MENDES EN et al. Metronidazole-resistant Helicobacter pylori in a developing country. Am J Gastroenterol 1993; 88: 322-323.

23. MENDONCA S, ECCLISSATO C, SARTORI MS et al. - Prevalence of Helicobacter pylori resistance to metronidazole, clarithromycin, amoxicillin, tetracycline, and furazolidone in Brazil. Helicobacter 2000; 5: 79-83.

24. DANI R, QUEIROZ DM, DIAS MG et al. - Omeprazole, clarithromycin and furazolidone for the eradication of Helicobacter pylori in patients with duodenal ulcer. Aliment Pharmacol Ther 1999; 13: 1647-1652.

25.ZATERKA S, EISIG JN, CHINZON D et al. - Five-day and ten-day triple therapy (amoxicillin, furazolidone and metronidazole) in the treatment of duodenal ulcer. Rev Hosp Clin Fac Med S Paulo 1996; 51: 162-165.

26. FRANCO JMM, CASTRO FJ, PASSOS MCF et al. - Helicobacter pylori: erradicação em curto prazo com o esquema Belo Horizonte modificado. G E D 1994; 13: 81-84.

27. CHEHTER EZ, SILVA FM, EISIG JN et al. - H. pylori eradication: High efficacy week treatment with clarithromycin 500mg bid, amoxicillin 1,0g bid plus lansoprazole $30 \mathrm{mg}$ bid in São Paulo Brazil. Am J Gastroenterolol 1999; 94: A118.

28. DI MARIO F, DAL BÓ N, GRASSI AS et al. - Azithromycin for the cure of Helicobacter pylori infection. Am J Gastroenterol 1996; 91: $264-267$.

29. CASELLI M, TREVISANI L, TURSI A et al. - Short-term low-dose triple therapy with azithromycin, metronidazole and lansoprazole appears highly effective for the eradication of Helicobacter pylori. Eur J Gastroenterol Hepatol 1997; 9: 45-48.

30. CAMMAROTA G, TURSI A, PAPA A et al. - Helicobacter pylori eradication using one-week low-dose lansoprazole plus amoxycillin and either clarithromycin or azithromycin. Aliment Pharmacol Ther 1996; 10: 997-1000.

31. VCEV A; STIMAC D; IVANDIC A et al. - Pantoprazole, amoxicillin and either azithromycin or clarithromycin for eradication of Helicobacter pylori in duodenal ulcer. Aliment Pharmacol Ther 2000; 14: 69-72.

32. CHEY WB, FISHER L, BARNETT J et al. - Low-dose versus highdose azithromycin triple therapy for Helicobacter pylori infection. Aliment Pharmacol Ther 1998; 12: 1263-1267.

33. COELHO LGV, VIEIRA WLS, PASSOS MCF et al. - Azithromycin, furazolidone and omeprazole: a promising low-dose, low cost, short-term, anti-H. pylori triple therapy. Gastroenterology 1998; 14:A94.

34. LABENS J, LEVERKUS F \& BORSCH G - Omeprazole plus amoxicillin for cure of Helicobacter pylori infection. Factors influencing the treatment success. Scand J Gastroenterol 1994; 29: $1070-1075$. 
35. GODDARD AF \& SPILLER RC - Helicobacter pylori eradication in clinical practice: one-week low-dose triple therapy is preferable to classical bismuth based triple therapy. Aliment Pharmacol Ther 1996; 10:1009-1013.

36. LIND T, MÉGRAUD F, UNGE P et al. - The MACH2 Study: Role of omeprazole in eradication of Helicobacter pylori with 1-week triple therapies. Gastroenterology 1999; 116: 248-253.

37. RETSEMA J, GIRARD A, SCHELKLY W et al. - Spectrum and mode of action of azithromycin (CP-62,993), a new 15-membered-ring macrolide with improved potency against gram-negative organisms. Antimicrob Agents Chemother 1987; 31:1939-1947.
38. MALFERTHEINER P - Compliance, adverse events and antibiotic resistance in Helicobacter pylori treatment. Scand J Gastroenterol 1993; 28(suppl 196): 34-37.

39. KUIPERS EJ - Helicobacter pylori, acid and omeprazole revisited: bacterial eradication and rebound hypersecretion. Gastroenterology 1999; 116: 479-483.

Received for publication on March 19, 2001 